\title{
A paediatric influenza update 100 years after the Skyros island Spanish flu outbreak
}

\author{
IOANNIS N. MAMMAS ${ }^{1}$, MARIA THEODORIDOU ${ }^{2}$, PRAKASH THIAGARAJAN ${ }^{3}$, ANGELIKI MELIDOU $^{4}$, \\ GEORGIA PAPAIOANNOU ${ }^{5}$, PARASKEVI KOROVESSI ${ }^{6}$, CHRYSSIE KOUTSAFTIKI $^{7}$, \\ ALEXIA PAPATHEODOROPOULOU ${ }^{8}$, MARCOS CALACHANIS ${ }^{9}$, \\ TINA DALIANIS $^{10}$ and DEMETRIOS A. SPANDIDOS ${ }^{1}$
}

${ }^{1}$ Department of Clinical Virology, School of Medicine, University of Crete, 71003 Heraklion;

${ }^{2}$ First Department of Paediatrics, 'Aghia Sophia' Children's Hospital, University of Athens School of Medicine, 11527 Athens, Greece; ${ }^{3}$ Neonatal Unit, Division for Women's \& Children Health, Noble's Hospital, IM4 4RJ Douglas, Isle of Man, British Isles; ${ }^{4}$ Second Laboratory of Microbiology, School of Medicine, Aristotle University of Thessaloniki, 54124 Thessaloniki, Greece; ${ }^{5}$ Department of Paediatric Radiology, 'Mitera' Children's Hospital, 15123 Athens, Greece;

${ }^{6}$ Department of Paediatrics, and ${ }^{7}$ Paediatric Intensive Care Unit (PICU), 'Penteli' Children's Hospital, 15236 Penteli;

${ }^{8}$ Paediatric Intensive Care Unit (PICU), 'P. and A. Kyriakou' Children's Hospital, 11527 Athens;

${ }^{9}$ Department of Paediatric Cardiology, 'Penteli' Children's Hospital, 15236 Penteli, Greece;

${ }^{10}$ Karolinska Institutet, Karolinska University Hospital, SE-117 77 Stockholm, Sweden

Received March 6, 2019; Accepted April 16, 2019

DOI: $10.3892 /$ etm.2019.7515

\begin{abstract}
This year marks the 100th anniversary of the 1918 Spanish flu outbreak on the Greek Aegean Sea island of Skyros, which devastated its population in less than 30 days. According to Constantinos Faltaits's annals published in 1919, the influenza attack on the island of Skyros commenced acutely 'like a thunderbolt' on the 27th of October, 1918 and was exceptionally severe and fatal. At that time, the viral cause of the influenza had not been detected, while the total number of victims of the Spanish flu outbreak has been estimated to have surpassed 50 million, worldwide. Almost one century after this Aegean Sea island's tragedy, the '4th Workshop on Paediatric Virology', organised on the 22nd of September, 2018 in Athens, Greece, was dedicated to the 100 years of the 'Spanish' flu pandemic. This review article highlights the plenary and key lectures presented at the workshop on the recent advances on the epidemiology, clinical management and prevention of influenza in childhood.
\end{abstract}

Correspondence to: Professor Demetrios A. Spandidos, Department of Clinical Virology, School of Medicine, University of Crete, Heraklion 71003, Greece

E-mail: spandidos@spandidos.gr

Key words: paediatric virology, influenza, H1N1, vaccination, antiviral drugs, radiology, neurological complications, myocarditis, Paediatric Intensive Care Unit, probiotics

\section{Contents}

1. Introduction

2. Overview of influenza vaccination in children

3. Management of influenza with antiviral drugs

4. Epidemiology of influenza in childhood

5. Chest radiology issues of influenza in children

6. Neurological complications of influenza in children

7. Myocarditis and influenza in children

8. Influenza as a cause of admission to the PICU

9. Paediatric healthcare workers and vaccination against influenza

10. Probiotics and influenza in childhood

\section{Introduction}

In 1918, on the Greek Aegean Sea island of Skyros, the largest and southernmost island of the Northern Sporades, during the time of the celebration for Saint Demetrios, approximately one third of the whole island's population died of the 'Spanish' influenza pandemic in less than 30 days (1). Constantinos Faltaits, a prominent writer and journalist of the beginning of the last century, wrote a unique report of the Skyros flu outbreak in the whole Hellenic literature similar to Hippocrates's analysis of Perynthos influenza-like outbreak almost 2,400 years ago (2). According to his annals published in 1919, the influenza attack on Skyros island was exceptionally severe and fatal (1). It began on the 27th of October, 1918, and its onset was described as acute 'like a thunderbolt' and among the 3,200 inhabitants of Skyros, almost 2,000 were infected and 1,000 died (1). His descriptions report extremely touching details about this Greek island's tragedy. 
At that time, the viral cause of influenza, largely targeting healthy young adults, had not been detected, while the total number of victims of the Spanish flu outbreak surpassed 50 million, worldwide. In the nearby islands of Euboea and Andros, similar family cases attacked by influenza have been reported by local writers (3). The deaths were in family groups, while several cases of children, who managed to survive despite losing both of their parents, have been reported. Almost one century after this Aegean Sea island tragedy, the '4th Workshop on Paediatric Virology', which was held in Athens on September 22, 2018, was dedicated to the 100 years of the 'Spanish' flu pandemic on Skyros island (4). This workshop was organized by the Paediatric Virology Study Group (PVSG) in the context of the 23rd World Congress on Advances in Oncology and the 22nd International Symposium on Molecular Medicine. Its educational programme focused on two viral infections with great paediatric interest, influenza and human papillomavirus (HPV). The workshop was co-chaired by Professor Tina Dalianis, Professor of Tumour Virology at Karolinska Institutet (Stockholm, Sweden), Professor Maria Theodoridou, Emerita Professor of Paediatrics at the 'Aghia Sophia' Children's Hospital in Athens, President of the National Immunisation Committee and former President of the Hellenic Paediatric Infectious Diseases Society (Greece), Dr Prakash Thiagarajan, Clinical Director and Consultant Neonatologist at Nobles Hospital on the Isle of Man (British Isles) and Ioannis N. Mammas, Consultant Paediatrician on the island of Euboea (Greece) and Coordinator of the Paediatric Virology Study Group (PVSG). This review article highlights the plenary and key lectures presented at the workshop on the recent advances on the epidemiology, clinical management and prevention of influenza in childhood (Table I).

\section{Overview of influenza vaccination in children}

Immunization against seasonal influenza has proven to be the most effective method for the prevention of the illness offering the best defence to children against acquiring the infection and spreading it to others (5-7). Immunization against seasonal influenza can reduce medical visits and missed school days and can prevent influenza-related hospitalizations and deaths in children (7). Historically, the first universal influenza vaccination for school children was implemented in Japan in 1962 in order to prevent influenza epidemics in the community (5). This strategy was abandoned in 1994. In the following years, it was well demonstrated that the protection of the older population by herd immunity was generated by the policy of universal vaccination of school children (8). Over the past decades, the recommendations for children's influenza vaccination have gradually changed and the target population has been expanded (9). The vaccination policy differs between countries, such as the USA, Canada and the UK. These large developed countries have issued recommendations for the vaccination of healthy children and adolescents of varying ages. It is worth noting that for the first time in 2004, healthy children aged 6-23 months of age were included in increased risk group. Currently, the influenza vaccine is recommended for healthy children of all ages. However, the majority of European countries, including Greece, have issued their own programmes implementing the approach of targeting groups at the highest risk of complications (10).
The influenza vaccines are multivalent and contain different viral subtypes. The composition is continuously changed in the anticipation of the expected prevalent influenza strains. The vaccines have a long history of safety in children, while prospective studies have evaluated the efficacy and immunogenicity. Children $<2$ years of age seem to have an inferior immunological response than those $>2$ years of age (11). The clinical effectiveness of influenza vaccines varies by year and setting. An important factor is related to how closely the vaccines are matched against circulating strains. The vaccines currently available are the trivalent inactivated influenza vaccines (IIV), the live attenuated influenza vaccine (LAIV) and recently, the quadrivalent IIV and the quadrivalent nasal spray LAIV; the last two formulations include two influenza $\mathrm{B}$ strains in addition to the A strains.

The history of influenza is characterized by a continuous effort to develop vaccines effective for the needs of the recipients. Nevertheless, the uptake of the vaccine even in high-risk children remains very low (5). The main reasons for the inadequate vaccine coverage are the concerns regarding the safety and effectiveness of the vaccine (12). A new promising era is maternal immunization. The vaccine uptake from pregnant women has the potential to change the epidemiology of influenza infection and improve maternal and neonatal health (13). The future perspectives for influenza include vaccines providing broader and long-lasting protection and the most important regain of public confidence to immunization.

\section{Management of influenza with antiviral drugs}

Antiviral medications play a key role in the clinical management of children with influenza, and may prove to be beneficial, particularly in the hospital setting (14-21). Antiviral therapy has been associated with the prevention of disease or complications among patients exposed to the virus, a shortened duration of illness among acutely-ill patients and the reduction of morbidity and mortality among patients with severe infection (22). A high index of suspicion should be maintained for the diagnosis of antiviral-resistant influenza, particularly among immunocompromised patients, patients with treatment failure or progressive infection despite adequate therapy or contacts of individuals known to be infected with resistant strains, although evidence of the relative efficacy to choose between the available antiviral medications is limited (23). Safety information and side-effect profiles are also limited for some of these drugs.

The use of the available antiviral drugs for the treatment of influenza, Oseltamivir, Zanamavir (inhaled and injectable, Peramavir (parenteral) and Amantadine, is based on the patient (whether high-risk or not), the type of infection, known resistance patters and co-morbidities in the patients (14). Drugs such as Peramavir remain unlicensed in children, but have been granted special permission by the US Food and Drug Administration (FDA) for use in an outbreak. Recent influenza A viruses are resistant to Amantadine, and thus it cannot be currently recommended. All patients with complicated or progressive influenza, including children at all ages, should be treated with antiviral drugs, regardless of the risk factors and immune status. The pharmacological properties, dosage, side-effects and mode of actions for the major antiviral drugs are summarized in Table II. For hospitalized infants and 
Table I. The top key messages of the '4th Workshop on Paediatric Virology' on paediatric influenza.

Prevention of influenza

Management of influenza

Epidemiology of influenza

Influenza radiology

Influenza and myocarditis

Influenza and PICU

Influenza and probiotics
Immunization against seasonal influenza has proven to be the most effective method for the prevention of the illness and is crucial both to protect children and to indirectly protect the vulnerable population.

Educational programmes that provide information about the benefits of the immunization, clarify fears and misconceptions about the vaccines and moreover easy access to the vaccine, may help to reverse the low coverage rate among HCWs and children as well.

Antiviral medications play a key role in the clinical management of children with influenza, particularly in the hospital setting.

For hospitalized infants and children, antiviral therapy should be commenced as soon as influenza is clinically suspected or at least within $48 \mathrm{~h}$ from the onset of the illness.

To date, two influenza A subtypes, $\mathrm{A}(\mathrm{H} 1 \mathrm{~N} 1) \mathrm{pdm} 09$ and $\mathrm{A}(\mathrm{H} 3 \mathrm{~N} 2)$, and two influenza B lineages, B/Yamagata and B/Victoria, co-circulate in humans and cause considerable morbidity and mortality in children.

Abnormal chest radiographs are rather uncommon in children with a mild and self-limited clinical course of influenza.

HRCT is of substantial value when the radiographic findings are subtle and in the assessment of complications.

In a child with acute encephalopathy and bilateral symmetrical involvement of the thalami, putamen, internal capsule, brainstem, cerebellum and periventricular white matter the suspicion for ANE should be raised.

Seasonal influenza can cause myocarditis in children, which can be presented with fever, myalgias, palpitations, or dyspnoea on exertion.

In paediatric cases of fulminant progression of myocarditis, the identification of signs and symptoms suggesting greater severity should be immediate.

Prompt cardiological examination with the use of echocardiography is important for the early detection and follow-up of the myocardial dysfunction.

Influenza may cause severe disease that can be occasionally fatal, especially in high-risk groups; due to influenza's complications children may require admission to the Paediatric Intensive Care Unit (PICU).

Further studies are required to elucidate the effectiveness of probiotics in the prevention of influenza in childhood.

HCWs, health care workers; HRCT, high-resolution computed tomography; ANE, acute necrotizing encephalopathy; PICU, Paediatric Intensive Care Unit.

children, antiviral therapy should be commenced as soon as influenza is clinically suspected or at least within $48 \mathrm{~h}$ from the onset of the illness. The algorithm presented in Fig. 1 is a useful decision-making tool for deciding whether to commence antiviral medication and if so, to select the correct one.

\section{Epidemiology of influenza in childhood}

Seasonal influenza is an acute viral infection that spreads efficiently from individual to individual, particularly among children that are nowadays considered to be the main drivers of influenza infection (24). In terms of transmission and spread, seasonal influenza is rapidly transmitted in crowded areas, particularly in schools and nurseries. When an infected person coughs or sneezes, infectious droplets are dispersed through the air and infect close contacts directly or indirectly through contaminated surfaces (25). Children are considered to be super-spreaders that may disperse higher viral loads and for longer time periods. In temperate climates, seasonal epidemics occur mainly during winter. Currently there are two types of influenza viruses that cause outbreaks and seasonal epidemics: types A and B. Influenza A viruses are divided into subtypes, based on the type of haemagglutinin and neuraminidase, which are the two external glycoproteins and the main antigens of the virus. Currently, co-circulating in humans are two influenza A subtypes (Table III): A(H1N1)pdm09 and A(H3N2), and two influenza B lineages: B/Yamagata and B/Victoria (25). Each year, different combinations of influenza types/subtypes co-circulate and dominate. The variability of the circulating strains and differences in their genetic and antigenic characteristics drive the re-evaluation of the influenza vaccine for each season by the World Health Organization (WHO). 


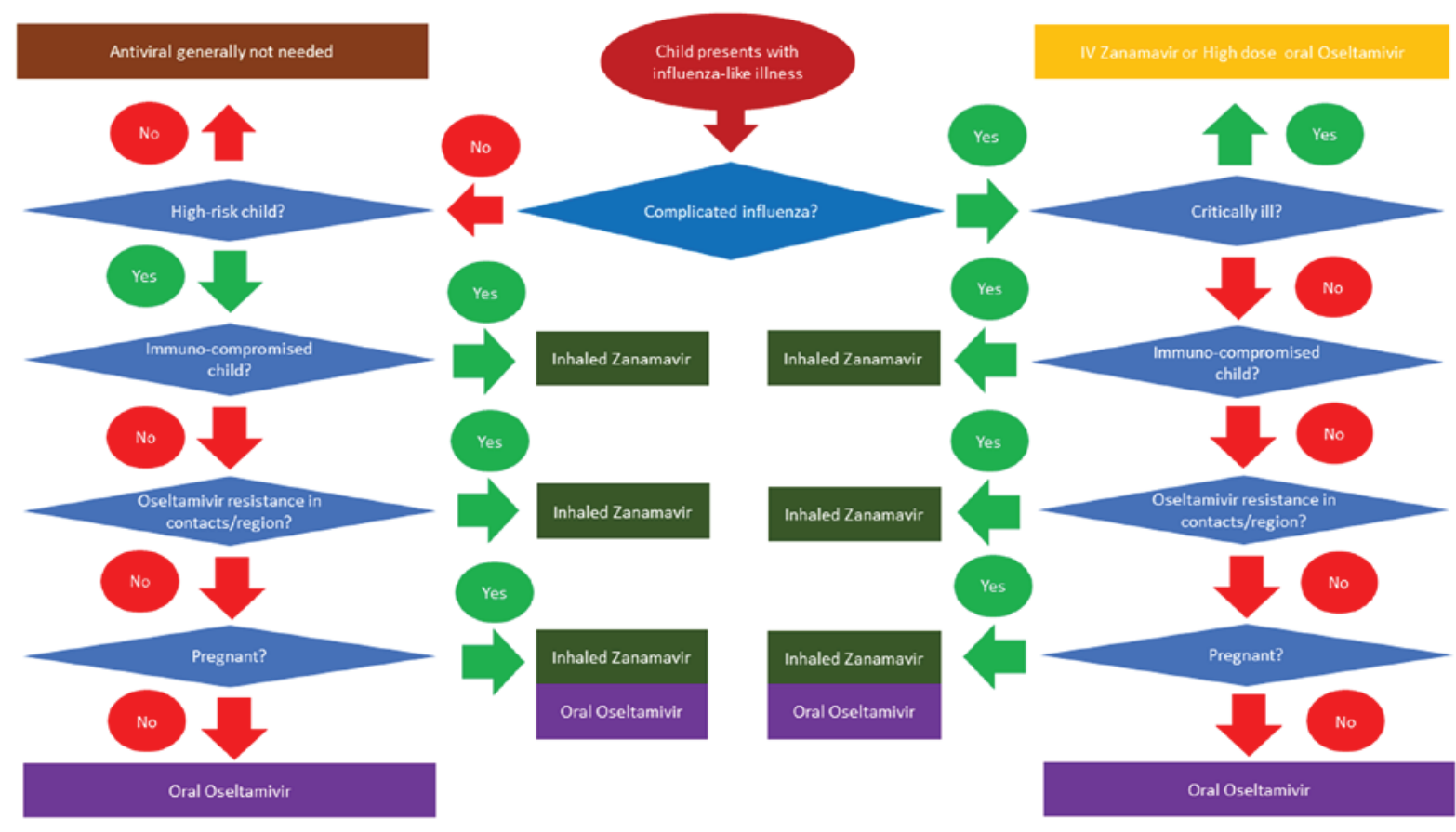

Figure 1. Decision-making algorithm for antiviral medication in children with influenza.

Seasonal influenza is a public health concern, as it is present worldwide and affects individuals of any age group. To date, research has focused on identifying which types and subtypes mostly circulate among children (25-32). It is considered that the epidemiology of seasonal influenza is indeed affected by age and the previous immunity patterns of the individuals. The youngest age groups are usually the most affected $(27,28)$, while the $<5$ and the $>65$ years age groups have a higher risk of severe outcomes due to influenza infections. The 5-14 year age group has been shown to be more likely infected by influenza type B viruses, while the 15-64 year age group by influenza type A viruses (27). As regards the influenza A subtypes, it has been shown that $\mathrm{A}(\mathrm{H} 1 \mathrm{~N} 1) \mathrm{pdm} 09$ mostly affects the younger age groups, while $\mathrm{A}(\mathrm{H} 3 \mathrm{~N} 2)$ the older age groups (31). In another report, it was demonstrated that $\mathrm{B} /$ Victoria viruses are more common among younger age groups than $\mathrm{B} /$ Yamagata viruses (32). On the other hand, it has been concluded that the clinical presentation of disease is similar among those patients that consulted general practitioners irrespective of the influenza type from which they were infected $(29,31)$.

\section{Chest radiology issues of influenza in children}

Influenza can cause severe morbidity and mortality in previously healthy children, projecting with respiratory and less often, central nervous system disease (33-36). Influenza A viruses are an important cause of pandemic respiratory disease (37). For the adult patients affected, a chest radiography provides adequate information, revealing ground-glass opacities, areas of consolidation or a mixed pattern of both. However, abnormal chest radiographs are rather uncommon in children with a mild and self-limited clinical course (33). High-resolution computed tomography (HRCT) of the chest is of substantial value when the radiographic findings are subtle and in the assessment of complications (34-37). HRCT usually reveals peribronchial markings with hyper-inflation and ill-defined patchy consolidation with mediastinal lymph node enlargement, pleural effusion and pneumomediastinum $(33,34)$. In children with a more severe clinical course bilateral, symmetrical and multifocal areas of consolidation, often associated with ground-glass opacities, with peribronchial or subpleural distribution, are the predominant radiographical finding, evident even on chest radiographs (36). Albeit these findings are non-specific of influenza infection, bilateral and usually peripheral, subpleural, peribronchial and sometimes lobular pattern of distribution should raise the suspicion in presence of the corresponding clinical scenario $(35,36)$. Rarely, parenchymal abnormalities are diffuse or even unilateral (33-36). Bilateral widespread consolidation is usually associated with severe prognosis (37). The pattern of scattered consolidation should be differentiated from secondary bacterial pneumonia, based on the clinical and laboratory findings. A note is made of the understudied lung pattern during the recovery phase, when multifocal areas of consolidation may be demonstrated and should be differentiated from secondary bacterial infection (37). Even in cases of benign evolution, the consolidations may progress to chronic sequelae, such as linear opacities or air-trapping, which may reflect organizing pneumonia or bronchiolitis, respectively (37).

\section{Neurological complications of influenza in children}

Neurological complications are reported in $10 \%$ of children hospitalized with influenza; these include the potentially fatal acute necrotizing encephalopathy (ANE), encephalopathy/encephalitis, seizures, Guillain-Barré syndrome, myelitis, stroke and Reye syndrome $(33,38)$. Seizures are the most common neurological complication followed by encephalitis/encephalopathy (38-40). ANE, first described in 1995 in Japan, is the most severe form of acute non-inflammatory encephalopathy, representing a more recently described 
Table II. Pharmacological properties, dosage, side-effects and mode of actions for the major antiviral drugs against influenza.

\begin{tabular}{|c|c|c|c|c|c|}
\hline Drug & $\begin{array}{l}\text { Mechanism } \\
\text { of action }\end{array}$ & Dosage & Side-effects & $\begin{array}{c}\text { Resistance } \\
\text { profile }\end{array}$ & Remarks \\
\hline Oseltamivir & $\begin{array}{l}\text { Neuraminidase } \\
\text { inhibition }\end{array}$ & $\begin{array}{l}2.5 \mathrm{mg} / \mathrm{kg} \text { twice a day for children } \\
1-3 \mathrm{months}, 3.0 \mathrm{mg} / \mathrm{kg} \\
\text { twice a day for children } 3-12 \text { months. } \\
\text { For } 1-13 \text { years the recommended } \\
\text { oseltamivir dose is } 30 \mathrm{mg} \text {, } \\
45 \mathrm{mg}, 60 \mathrm{mg} \text { or } 75 \mathrm{mg} \\
\text { twice a day for children weighing } \\
<15 \mathrm{~kg}, 15-23 \mathrm{~kg}, 23-40 \mathrm{~kg} \\
\text { or }>40 \mathrm{~kg} \text {, respectively }\end{array}$ & $\begin{array}{l}\text { Gastrointestinal } \\
\text { disturbances } \\
\text { Rarely hepatitis, } \\
\text { arrhythmia and } \\
\text { Stevens-Johnson }\end{array}$ & $\begin{array}{l}\text { Uncommon } \\
\text { H275Y } \\
\text { mutation in } \\
\text { H1N1 strains } \\
\text { More rare } \\
\text { mutations in } \\
\text { other subtypes }\end{array}$ & $\begin{array}{l}\text { Dose reduction } \\
\text { in renal } \\
\text { failure }\end{array}$ \\
\hline Zanamivir & $\begin{array}{l}\text { Neuraminidase } \\
\text { inhibition }\end{array}$ & $\begin{array}{l}10 \text { mg twice a day for } \\
5 \text { days (only for } \\
\text { children over } 5 \text { years) }\end{array}$ & $\begin{array}{l}\text { Rarely } \\
\text { bronchospasm } \\
\text { or angio-oedema }\end{array}$ & $\begin{array}{l}\text { Rare } \\
\text { I223R mutation } \\
\text { detected } \\
\text { in } \sim 10 \text { cases of } \\
\text { H1N1 (2009) } \\
\text { worldwide }\end{array}$ & $\begin{array}{l}\text { Can be } \\
\text { given via } \\
\text { intravenous } \\
\text { route }\end{array}$ \\
\hline $\begin{array}{l}\text { Peramivir } \\
\text { (unlicensed) }\end{array}$ & $\begin{array}{l}\text { Neuraminidase } \\
\text { inhibition }\end{array}$ & $\begin{array}{l}\text { Birth - } 30 \text { days, } 6 \mathrm{mg} / \mathrm{kg} \text {; } \\
31 \text { days - } 90 \text { days, } 8 \mathrm{mg} / \mathrm{kg} \text {; } \\
91 \text { days - } 180 \text { days, } 10 \mathrm{mg} / \mathrm{kg} \text {; } \\
181 \text { days - } 5 \text { years, } 12 \mathrm{mg} / \mathrm{kg} \text {; } \\
6 \text { years - } 17 \text { years, } 10 \mathrm{mg} / \mathrm{kg}\end{array}$ & $\begin{array}{l}\text { Gastrointestinal } \\
\text { disturbances, } \\
\text { psychiatric } \\
\text { abnormalities, } \\
\text { neutropenia }\end{array}$ & $\begin{array}{l}\text { Rare } \\
\text { H275Y mutation } \\
\text { reduces efficacy }\end{array}$ & $\begin{array}{l}\text { Dose reduction } \\
\text { in renal failure. } \\
\text { Unlicensed } \\
\text { drug }\end{array}$ \\
\hline Amantadine & $\begin{array}{l}\text { M2 channel } \\
\text { inhibitor }\end{array}$ & $\begin{array}{l}1 \text { to } 9 \text { years: } 5 \mathrm{mg} / \mathrm{kg} \text { orally } \\
\text { per day in } 2 \text { divided doses; } \\
\text { not to exceed } 150 \mathrm{mg} / \text { day; } \\
10 \text { years or older, }<40 \mathrm{~kg} \text { : } \\
5 \mathrm{mg} / \mathrm{kg} \text { orally per day } \\
10 \text { years or older, } 40 \mathrm{~kg} \text { or more: } \\
100 \mathrm{mg} \text { orally twice a day }\end{array}$ & $\begin{array}{l}\text { Confusion, } \\
\text { insomnia, } \\
\text { Exacerbation of } \\
\text { underlying } \\
\text { neurological } \\
\text { conditions }\end{array}$ & $\begin{array}{l}\text { Common } \\
\text { H1N1 (2009) } \\
\text { 100\% resistant } \\
\text { Varying rates in } \\
\text { H3N2/seasonal } \\
\text { H1N1/influenza B }\end{array}$ & $\begin{array}{l}\text { Dose reduction } \\
\text { in renal failure }\end{array}$ \\
\hline
\end{tabular}

Table III. Co-circulating influenza types in children.

Influenza A subtypes

$\mathrm{A}(\mathrm{H} 1 \mathrm{~N} 1) \mathrm{pdm} 09$

$\mathrm{A}(\mathrm{H} 3 \mathrm{~N} 2)$

Influenza B lineages

B/Yamagata

B/Victoria

para-infectious condition, considered to differ from the classical acute disseminated encephalomyelitis (ADEM). Patients present with acute and rapid neurological deterioration and often intractable seizures preceded by febrile illness. It has been most often associated with influenza infections $(\mathrm{A} / \mathrm{H} 1 \mathrm{~N} 1$ and A/H3N2), but other viruses have also been reported to serve as a triggering factor (33). ANE carries a high morbidity and mortality rate (30\%) and it is reported to develop in $1 \%$ of the children with influenza and neurologic complications (38-40). The majority of survivors present severe neurodevelopmental morbidity.
Imaging patterns are typical with evidence of bilateral, symmetrical areas of necrosis and haemorrhage in the thalami, the basal ganglia and occasionally the brain stem, and additional diffuse or focal areas of oedema in the cerebral and cerebellar white matter (38). On apparent diffusion coefficient maps, there is a laminar, target or tricolour pattern of involvement of the thalami (39). Overall, in a child with acute encephalopathy and bilateral symmetrical involvement of the thalami, putamen, internal capsule, brainstem, cerebellum and periventricular white matter, the suspicion for ANE should be raised. This is associated with vasculopathy and the breakdown of the blood-brain barrier; however, the detailed pathogenesis remains uncertain. Emphasis should be made regarding the need for a high index of suspicion to establish early diagnosis together with the generalized measures to prevent influenza outbreak (40).

\section{Myocarditis and influenza in children}

Myocarditis is an inflammatory condition of the heart muscle that can result from various aetiologies, such as autoimmune disorders, bacterial, fungal or protozoal infections, and viruses that are its most common cause (41-43). In paediatric patients, 
fulminant myocarditis corresponds to $30-40 \%$ of the cases of myocarditis and has a mortality rate of up to $48 \%$ (44). The exact prevalence of myocarditis is not known $(45,46)$. The annual incidence of dilated cardiomyopathy in children younger than 18 years is reportedly 0.57 cases $/ 100,000$ per year, while $46 \%$ of them were diagnosed as being caused by myocarditis (47). Hence, the incidence of myocarditis in children could be estimated as approximately 0.3 cases/year per 100,000 children. Myocardial involvement in infections by influenza ranges from 0 to $11 \%$, depending on the criteria used to define myocarditis (48). Influenza A virus subtype H1N1, which was responsible for the 2009 influenza pandemic, plays a significant role in the pathogenesis of acute myocarditis. However, there are few cases of fulminant myocarditis due to H1N1 influenza reported in the literature, particularly in children $(48,49)$.

Children with myocarditis may present with a variety of symptoms, most of which are non-specific, including fever, myalgia, palpitations, or dyspnoea upon exertion. Surveillance reports have revealed fever and/or gastrointestinal symptoms as the most frequent initial symptoms (44). Children's clinical conditions may precipitate to haemodynamic instability, the rapid worsening of the patient's condition, eventually requiring biventricular mechanical support with cardiogenic shock and the potential presentation of fatal arrhythmias with sudden death. Importantly, myocarditis may be the cause of dilated cardiomyopathy through inflammatory autoimmune processes (50). Until recently, the confirmatory diagnostic procedure for myocarditis was endomyocardial biopsy; however, it has now been replaced by the cardiac magnetic resonance imaging (MRI) $(51,52)$. Echocardiography plays a paramount role in the diagnosis and follow-up of myocardial dysfunction, and is able to exclude other causes of heart failure, such as congenital heart disease and valvular or pericardial diseases, and helps to identify the fulminant course of the disease. Findings include global left ventricular dysfunction with or without pericardial effusion, a variable degree of myocardial dilation and atrioventricular valvular regurgitation.

The treatment of paediatric myocarditis consists of medications that significantly improve left ventricular systolic dysfunction. Recommendations in paediatric patients (53-55) emphasize that supportive medical therapy should be the primary therapy for acute presentation. The treatment of heart failure and left ventricular dysfunction should proceed according to the established guidelines of the American Heart Association (AHA), the American College of Cardiology and the European Society of Cardiology $(56,57)$. These guidelines suggest angiotensin-converting enzyme inhibition for asymptomatic left ventricular dysfunction), treatment implementation with selective $\beta$-blocker in symptomatic heart failure, and the use of inotropic agents with mechanical ventilatory or circulatory support for patients with rapid clinical deterioration. High-dose intravenous immunoglobulin, antiviral and antibacterial therapies may also be of therapeutic benefit.

\section{Influenza as a cause of admission to the PICU}

Influenza viruses cause a significant disease burden and due to the associated complications, children with influenza may require admission to the Paediatric Intensive Care Unit (PICU) $(58,59)$. Children at a higher risk of complications are considered to be those under 59 months of age and with concomitant medical conditions (cardiac, pulmonary, renal, metabolic, neurodevelopmental, liver and haematological diseases), or suffer from immunosuppression, such as patients with HIV/AIDS, malignancies, or those receiving chemotherapy, or steroids $(60,61)$. According to the data from the Centers for Disease Control and Prevention (CDC), 172 influenza-related paediatric deaths were reported in the USA during the season 2017-2018 $(62,63)$. During the same period, the similar national centre in Greece recorded 111 cases of severe influenza infection, among which 9 cases in children and adolescents and 42 deaths, 1 in a child $<5$ years old (64).

Seasonal influenza, similar to other viral infections, significantly contributes to the expression of acute respiratory distress syndrome (ARDS), which represents the leading cause of admissions to the PICU (65). Other complications requiring admission to the PICU are myocarditis (66), life-threatening arrhythmias and neurological disorders, ranging from simple febrile convulsions to more severe encephalitis/encephalopathy. Influenza-associated encephalopathy is characterized by an altered level of consciousness and seizure activity within a few days of symptom onset and is rapidly progressive (62). Other neurological disorders include ANE, Guillain-Barre syndrome, traverse myelitis and Reye syndrome in individuals receiving acetylsalicylic acid (67). Rhabdomyolysis is another more severe manifestation, which can lead to acute renal failure and the need for renal replacement therapy (65). As presented in Table IV, during the period 2011-2018, at 'P. and A. Kyriakou' Children's Hospital in Athens, Greece, among the 17 children admitted to the PICU due to complications from influenza infection (confirmed by the laboratory), 7 (41\%) children experienced central nervous system disorders - 3 febrile convulsions, 2 ANE and 2 non-specific encephalopathy (58). Respiratory distress was responsible for $6(35 \%)$ of admissions, half of which among children with co-morbidities, whereas 4 patients mentioned cardiovascular symptoms. Influenza A was confirmed in the majority of cases (12 children, 70,5\%). No death was recorded during hospitalization, although 5 patients developed permanent defects.

\section{Paediatric healthcare workers and vaccination against influenza}

Seasonal influenza is responsible for $>500,000$ deaths each year and 3-5 million cases annually (68-71). Children are considered as vectors for the spread of influenza $(70,72)$. Healthcare workers (HCWs) are exposed to patients with influenza in the workplace; thus, they are at risk of occupationally-acquired influenza that may be transmitted to their patients and other colleagues, more frequently than the general population $(68,69,73,74)$. It has been reported that the annual incidence of infection among unvaccinated HCWs is 3-fold higher than among those vaccinated $(68,69,75)$. To date, it has been well demonstrated that the immunization of HCWs against seasonal influenza indirectly protects the health of their patients, particularly those who are at high-risk, including infants, pregnant women, the elderly and the immunocompromised $(74,76)$. However, despite recommendations, as well as evidence on the efficacy of the vaccine, the coverage rate among HCWs remains unacceptably low, with a wide variation among countries (i.e., 
Table IV. Distribution of risk factors and complications among admissions to the PICU during the period 2011-2018 at 'P. and A. Kyriakou' Children's Hospital in Athens, Greece.

\begin{tabular}{|c|c|c|c|}
\hline Characteristics & $\begin{array}{l}\text { All patients } \\
\qquad n=17\end{array}$ & $\begin{array}{c}\text { Influenza A } \\
n=12\end{array}$ & $\begin{array}{l}\text { Influenza } \\
\qquad \mathrm{n}=5\end{array}$ \\
\hline \multicolumn{4}{|l|}{ Sex, n $(\%)$} \\
\hline Male & $8(47)$ & $6(50)$ & $2(40)$ \\
\hline Female & $9(53)$ & $6(50)$ & $3(60)$ \\
\hline \multicolumn{4}{|l|}{ Age group, n (\%) } \\
\hline$<6$ months & $4(23)$ & $4(33)$ & 0 \\
\hline $6-24$ months & $4(23)$ & $3(25)$ & $1(20)$ \\
\hline $2-5$ years & $3(18)$ & $3(25)$ & 0 \\
\hline $5-14$ years & $6(35)$ & $2(17)$ & $4(80)$ \\
\hline \multicolumn{4}{|c|}{ Chronic conditions, n (\%) } \\
\hline Yes & $6(35)$ & $3(25)$ & $3(60)$ \\
\hline No & $11(65)$ & $9(75)$ & $2(40)$ \\
\hline \multicolumn{4}{|l|}{ Complications, n (\%) } \\
\hline Febrile convulsions & $3(18)$ & $3(25)$ & 0 \\
\hline $\begin{array}{l}\text { Acute necrotizing } \\
\text { encephalopathy }\end{array}$ & $2(12)$ & $2(17)$ & 0 \\
\hline $\begin{array}{l}\text { Non-specific } \\
\text { encephalopathy }\end{array}$ & $2(12)$ & $1(8)$ & $1(20)$ \\
\hline Bronchiolitis & $2(12)$ & $2(17)$ & 0 \\
\hline Pneumonia & $2(12)$ & $1(8)$ & $1(20)$ \\
\hline Asthma & $1(6)$ & 0 & $1(20)$ \\
\hline ARDS & $1(6)$ & $1(8)$ & 0 \\
\hline Myocarditis & $3(18)$ & $2(17)$ & $1(20)$ \\
\hline $\begin{array}{l}\text { Non-specific } \\
\text { cardiovascular } \\
\text { symptoms }\end{array}$ & $1(6)$ & 0 & $1(20)$ \\
\hline
\end{tabular}

Days of PICU stay,

Median (range) $\quad 15.6(1-190) \quad 5.4(1-18) \quad 40.1(1-190)$

PICU, Paediatric Intensive Care Unit; ARDS, acute respiratory distress syndrome.

$53 \%$ in the UK vs. $5 \%$ in Poland) (68-70). Still, the main reason for HCWs to receive the influenza vaccine, even in paediatric hospitals, is self-protection and secondly the protection of their patients $(74,76)$. Paediatricians seem to have a different attitude towards vaccination and a better knowledge compared with colleagues of other specialties (68-70). Despite these differences, their participation to the seasonal influenza programme, even at the hospital settings, remains extremely low (76).

Thus far, the enforcement of mandatory immunization policies has achieved high coverage rates against influenza among paediatric HCWs (68). However, the most feasible practice seems to be the adoption of novel strategies and interventions that aim in changing behaviour against 'vaccine hesitancy', establishing scientific evidence and integrated health programme planning models $(69,73,77)$. An increased coverage can be achieved when better information and education is given regularly to the staff and at the same time easy, free and scheduled access to the vaccination is provided $(69,70,74,76)$. High coverage among paediatric HCWs may also lead to the increased coverage of children against influenza. Not surprisingly, there is a strong correlation between the vaccination status against seasonal influenza of the paediatric staff and the recommendation of the vaccines to children (71). Paediatric HCWs are the main referents for the vaccine related information, have positive influence to the families and they can act as vaccination advocates (71). Educational programmes that provide information about the benefits of the immunization, clarify fears and misconceptions about the vaccines and moreover easy access to the vaccine are expected to help to reverse the low coverage rate among HCWs.

\section{Probiotics and influenza in childhood}

Probiotics are defined as live microorganisms which, when administered in adequate amounts, confer a health benefit on the host (78). The respiratory tract is a suitable area for probiotic immune stimulation, as its mucosal surfaces are functionally linked to the common mucosal-associated lymphoid tissues. Over the past few years common viral infections, such as influenza, have been proposed as fairly new targets for probiotics (78-80).

On the basis of the available evidence, it appears that probiotics, at least those investigated thus far in clinical trials, when administered at adequate doses for at least 30 days, can decrease the incidence and duration of influenza, as well as decrease the severity of the symptoms in adults $(80,81)$. Apart from one small trial in Japan (82), to date, there are no trials conducted in children for the potential benefits of probiotics specifically for the influenza virus, at least to the best of our knowledge. According to the most recent Cochrane review (83), probiotics seem to be more effective than placebos in reducing the number of participants, who experience episodes of acute upper respiratory tract infection (URTI), the mean duration of an episode of acute URTI, antibiotic use and cold-related school absence. A systematic review and meta-analysis of 23 randomised controlled trials involving 6,269 children with URTI concluded that children supplemented with probiotics had fewer numbers of days of URTIs per person compared with children who had taken a placebo and had fewer numbers of days absent from day care/school. However, there was no statistically significant difference in the illness episode duration between probiotic intervention group and placebo group (84). On the other hand, a systematic review and a network meta-analysis $(85,86)$ regarding the benefit of probiotics in children with URTI found a lack of evidence to support the effect of probiotics on the incidence rate of respiratory infections in children and adolescents. It can be concluded that the current data are contradictory, and somewhat insufficient to strongly recommend their routine use (87).

As regards the influenza vaccination, there is also evidence from recent systematic reviews and meta-analysis for the beneficial effects of prebiotic/probiotic supplementation on the immunological response to influenza vaccine in adults $(88,89)$. The use of adjuvant prebiotics/probiotics may offer an inexpensive intervention that may contribute to the prevention of influenza following influenza vaccination. However, a high heterogeneity of existing evidence was noted, while there are no reports to date that include children, at least to the best of 
our knowledge $(90,91)$. Further studies are warranted, particularly in children, to elucidate the effectiveness of probiotics in the prevention of influenza and decide on the optimal strains, dose, and the timing and duration of supplementation, since there are many strains of probiotics with established immune modulatory effects yet to be tried.

\section{Acknowledgements}

The authors would like to thank all the participants, who attended the workshop and provided feedback so that further work on improving the programme can be achieved in the future.

\section{Funding}

No funding was received.

\section{Availability of data and materials}

Not applicable.

\section{Authors' contributions}

INM, MT, PT, TD and DAS conceived and designed this review article. INM, MT, PT, AM, GP, VK, CK, AP and MC researched the literature, performed critical analysis and review of the literature and drafted the manuscript. MT, PT, TD and DAS critically revised the article for important intellectual content. All authors have read and approved the final manuscript.

\section{Ethics approval and consent to participate}

Not applicable.

\section{Patient consent for publication}

Not applicable.

\section{Competing interests}

DAS is the Editor-in-Chief for the journal, but had no personal involvement in the reviewing process, or any influence in terms of adjudicating on the final decision, for this article. The other authors declare that they have no competing interests.

\section{References}

1. Faltaits C: Influenza in Skyros, Annals. Vasileiou Editions, Athens, 1919

2. Mammas IN and Spandidos DA: Paediatric Virology in the Hippocratic Corpus. Exp Ther Med 12: 541-549, 2016.

3. Mammas IN, Theodoridou M and Spandidos DA: The 'Spanish' flu outbreak at the islands of Skyros, Euboea and Andros 100 years ago. Int J Mol Med 42: S22, 2018.

4. Mammas IN, Theodoridou M and Spandidos DA: The 1918 Spanish flu outbreak that devastated a Greek island underlines past lessons that must never be forgotten. Acta Paediatr 107: 2034, 2018

5. Theodoridou M: Overview of influenza vaccination in children. Int J Mol Med 42: S17, 2018.

6. Fraaij PL and Heikkinen T: Seasonal influenza: The burden of disease in children. Vaccine 29: 7524-7528, 2011.

7. Munoz FM: The impact of influenza in children. Semin Pediatr Infect Dis 13: 72-78, 2002.
8. Reichert TA, Sugaya N, Fedson DS, Glezen WP, Simonsen $\mathrm{L}$ and Tashiro $\mathrm{M}$ : The Japanese experience with vaccinating schoolchildren against influenza. N Engl J Med 344: 889-896, 2001.

9. Grohskopf LA, Sokolow LZ, Broder KR, Walter EB, Bresee JS Fry AM and Jernigan DB; Advisory Committee on Immunization Practices: Prevention and Control of Seasonal Influenza with Vaccines: Recommendations of the Advisory Committee on Immunization Practices - United States, 2017-18 Influenza Season. MMWR Recomm Rep 66: 1-20, 2017.

10. American Academy of Pediatrics Committee on Infectious Diseases: Recommendations for influenza immunization of children. Pediatrics 113: 1441-1447, 2004.

11. Neuzil KM, Dupont WD, Wright PF and Edwards KM: Efficacy of inactivated and cold-adapted vaccines against influenza A infection, 1985 to 1990: The pediatric experience. Pediatr Infect Dis J 20: 733-740, 2001.

12. Jefferson T, Rivetti A, Di Pietrantonj C, Demicheli V and Ferroni E: Vaccines for preventing influenza in healthy children. Cochrane Database Syst Rev 8: CD004879, 2012.

13. Lafond KE, Englund JA, Tam JS and Bresee JS: Overview of influenza vaccines in children. J Pediatric Infect Dis Soc 2: 368-378, 2013.

14. Thiagarajan P: Antiviral drugs in the clinical management of children with influenza. Int J Mol Med 42: S18, 2018.

15. Food and Drug Administration (FDA): Emergency use authorization of Peramivir IV Fact Sheet for health care providers. Available at: https://www.fda.gov/downloads/drugs/drugsafety/postmarketdrugsafetyinformationforpatientsandproviders/ucm187811.pdf. 2009.

16. Drugs.com: Usual Dose for Influenza A. Available at: https:// www.drugs.com/dosage/amantadine.html\#Usual_Pediatric_Dose_ for_Influenza_A. 2017.

17. National Institute for Health and Care Excellence (NICE): Amantadine, oseltamivir and zanamivir for the treatment of influenza. Available at: http://guidance.nice.org.uk/TA168. 2009.

18. National Institute for Health and Care Excellence (NICE): Oseltamivir, amantadine (review) and zanamivir for the prophylaxis of influenza. Available at: http://guidance.nice.org.uk/ TA158. 2008

19. Department of Health (DH): Pandemic H1N1 (2009) influenza: clinical management guidelines for adults and children.https://renal. org/pandemic-h1n1-2009-influenza-clinical-management-guidelinesadults-children/. 2009.

20. World Health Organization (WHO): Clinical management of human infection with H1N1 (2009): revised guidance. Available at: http://www.who.int/csr/resources/publications/swineflu/ clinical_management/en/.2009.

21. World Health Organization (WHO): WHO guidelines for pharmacological management of pandemic influenza (H1N1) 2009 and other influenza viruses. Available at: http://www.who.int/csr/resources/ publications/swineflu/h1n1_use antivirals_20090820/en/.2010.

22. Health Protection Agency (HPA): HPA Review: The clinical effectiveness of neuraminidase inhibitors, including evidence from the 2009 influenza A/H1N1 pandemic. Available on request for non-HPA personnel at: email: pandemicflu@hpa.org.uk. 2010.

23. Public Health England (PHE): PHE guidance on use of antiviral agents for the treatment and prophylaxis of seasonal influenza. Version 9.1, January 2019. Available at: https://assets.publishing. service.gov.uk/government/uploads/system/uploads/attachment_ data/file/773369/PHE_guidance_antivirals_influenza.pdf.

24. Melidou A: Epidemiology of influenza types and subtypes in childhood. Int J Mol Med 42: S18, 2018.

25. World Health Organisation: Influenza (Seasonal). Available at: http://www.who.int/mediacentre/factsheets/fs211/en/.

26. Hayward AC, Fragaszy EB, Bermingham A, Wang L, Copas A, Edmunds WJ, Ferguson N, Goonetilleke N, Harvey G, Kovar J, et al; Flu Watch Group: Comparative community burden and severity of seasonal and pandemic influenza: Results of the Flu Watch cohort study. Lancet Respir Med 2: 445-454, 2014.

27. Beauté J, Zucs P, Korsun N, Bragstad K, Enouf V, Kossyvakis A, Griškevičius A, Olinger CM, Meijer A, Guiomar R, et al; European Influenza Surveillance Network: Age-specific differences in influenza virus type and subtype distribution in the 2012/2013 season in 12 European countries. Epidemiol Infect 143: 2950-2958, 2015.

28. Gioula G, Melidou A, Exindari M, Chatzopoulou E, Chatzidimitriou D and Malisiovas N: Laboratory surveillance of influenza virus in children under 10 years old, in northern Greece, during 2004-2010. Hippokratia 17: 17-19, 2013. 
29. Mosnier A, Caini S, Daviaud I, Nauleau E, Bui TT, Debost E, Bedouret B, Agius G, van der Werf S, Lina B, et al; GROG network: Clinical characteristics are similar across type $\mathrm{a}$ and $\mathrm{b}$ influenza virus infections. PLoS One 10: e0136186, 2015.

30. Cox NJ and Subbarao K: Global epidemiology of influenza: Past and present. Annu Rev Med 51: 407-421, 2000

31. Van Kerkhove MD, Vandemaele KA, Shinde V, JaramilloGutierrez G, Koukounari A, Donnelly CA, Carlino LO, Owen R, Paterson B, Pelletier L, et al; WHO Working Group for Risk Factors for Severe H1N1pdm Infection: Risk factors for severe outcomes following 2009 influenza A (H1N1) infection: A global pooled analysis. PLoS Med 8: e1001053, 2011.

32. Barr IG, Vijaykrishna D and Sullivan SG: Differential age susceptibility to influenza B/Victoria lineage viruses in the 2015 Australian influenza season. Euro Surveill 21: 21, 2016.

33. Papaioannou G: Radiology issues of influenza in children. Int J Mol Med 42: S18, 2018

34. Marchiori E, Zanetti G, D'Ippolito G, Verrastro CG, Meirelles GS, Capobianco J and Rodrigues RS: Swine-origin influenza A (H1N1) viral infection: Thoracic findings on CT. AJR Am J Roentgenol 196: W723-8, 2011.

35. Choi MJ, Lee YS, Lee JY and Lee KS: Novel influenza A (H1N1) virus infection in children: Chest radiographic and CT evaluation. Korean J Radiol 11: 656-664, 2010.

36. Lee EY, McAdam AJ, Chaudry G, Fishman MP, Zurakowski D and Boiselle PM: Swine-origin influenza a (H1N1) viral infection in children: Initial chest radiographic findings. Radiology 254: 934-941, 2010.

37. Marchiori E, Zanetti G, Hochhegger B, Rodrigues RS, Fontes CA, Nobre LF, Mançano AD, Meirelles GS and Irion KL: High-resolution computed tomography findings from adult patients with Influenza A (H1N1) virus-associated pneumonia. Eur J Radiol 74: 93-98, 2010.

38. McSwiney P, Purnama J, Kornberg A and Danchin M: A severe neurological complication of influenza in a previously well child. BMJ Case Rep: Oct 23, 2014 (Epub ahead of print). doi: 10.1136/bcr-2014-206930.

39. Achiriloaie A, Michelson D, Lei L, Denham L, Oberg K and Raghavan R: Acute postviral encephalopathy: Pathologic and radiologic correlation in an atypical case.ChildNeurolOpen:Jul21, 2016 (Epub ahead of print). doi: 10.1177/2329048X16658845.

40. Yoganathan S, Sudhakar SV, James EJ and Thomas MM: Acute necrotizing encephalopathy in a child with H1N1 influenza infection: A clinicoradiological diagnosis and follow-up. BMJ Case Rep: Jan 11, 2016 (Epub ahead of print). doi: 10.1136/bcr-2015213429.

41. Calachanis M: Myocarditis due to influenza: An update. Int J Mol Med 42: S19, 2018.

42. Magnani JW and Dec GW: Myocarditis: Current trends in diagnosis and treatment. Circulation 113: 876-890, 2006.

43. Gupta S, Markham DW, Drazner MH and Mammen PP Fulminant myocarditis. Nat Clin Pract Cardiovasc Med 5: 693-706, 2008

44. Saji T, Matsuura H, Hasegawa K, Nishikawa T, Yamamoto E, Ohki H, Yasukochi S, Arakaki Y, Joo K and Nakazawa M: Comparison of the clinical presentation, treatment, and outcome of fulminant and acute myocarditis in children. Circ J 76: 1222-1228, 2012.

45. Hsiao HJ, Hsia SH, Wu CT, Lin JJ, Chung HT, Hwang MS, Su WJ and Chang YS: Clinical presentation of pediatric myocarditis in Taiwan. Pediatr Neonatol 52: 135-139, 2011.

46. Ghelani SJ, Spaeder MC, Pastor W, Spurney CF and Klugman D: Demographics, trends, and outcomes in pediatric acute myocarditis in the United States, 2006 to 2011. Circ Cardiovasc Qual Outcomes 5: 622-627, 2012.

47. Towbin JA, Lowe AM, Colan SD, Sleeper LA, Orav EJ, Clunie S, Messere J, Cox GF, Lurie PR, Hsu D, et al: Incidence, causes, and outcomes of dilated cardiomyopathy in children. JAMA 296 1867-1876, 2006

48. Fineberg HV: Pandemic preparedness and response--lessons from the H1N1 influenza of 2009. N Engl J Med 370: 1335-1342, 2014.

49. Mamas MA, Fraser D and Neyses L: Cardiovascular manifestations associated with influenza virus infection. Int J Cardiol 130 304-309, 2008

50. Taremi M, Amoroso A, Nace HL and Gilliam BL: Influenza B-induced refractory cardiogenic shock: A case report BMC Infect Dis 13: 452, 2013.

51. Feldman AM and McNamara D: Myocarditis. N Engl J Med 343: $1388-1398,2000$.
52. Levi D and Alejos J: Diagnosis and treatment of pediatric viral myocarditis. Curr Opin Cardiol 16: 77-83, 2001.

53. Kühl U and Schultheiss H-P: Myocarditis in children. Heart Fail Clin 6: 483-496, viii-ix, 2010.

54. Levine MC, Klugman D and Teach SJ: Update on myocarditis in children. Curr Opin Pediatr 22: 278-283, 2010.

55. May LJ, Patton DJ and Fruitman DS: The evolving approach to paediatric myocarditis: A review of the current literature. Cardiol Young 21: 241-251, 2011.

56. Hunt SA, Abraham WT, Chin MH, Feldman AM, Francis GS Ganiats TG, Jessup M, Konstam MA, Mancini DM, Michl K, et al; American College of Cardiology Foundation; American Heart Association: 2009 focused update incorporated into the ACC/ AHA 2005 guidelines for the diagnosis and management of heart failure in adults: A report of the American College of Cardiology Foundation/American Heart Association Task Force on Practice Guidelines: Developed in collaboration with the International Society for Heart and Lung Transplantation. J Am Coll Cardiol 53 e1-e90, 2009.

57. Dickstein K, Cohen-Solal A, Filippatos G, McMurray JJ Ponikowski P, Poole-Wilson PA, Strömberg A, van Veldhuisen DJ, Atar D, Hoes AW, et al; ESC Committee for Practice Guidelines (CPG): ESC Guidelines for the diagnosis and treatment of acute and chronic heart failure 2008: The Task Force for the Diagnosis and Treatment of Acute and Chronic Heart Failure 2008 of the European Society of Cardiology. Developed in collaboration with the Heart Failure Association of the ESC (HFA) and endorsed by the European Society of Intensive Care Medicine (ESICM). Eur Heart J 29: 2388-2442, 2008

58. Papatheodoropoulou A, Koutsaftiki C and Papadatos J: Influenza complications in PICU. Int J Mol Med 42: S19, 2018.

59. Ruf BR and Knuf M: The burden of seasonal and pandemic influenza in infants and children. Eur J Pediatr 173: 265-276, 2014

60. Kaczmarek MC, Ware RS, Coulthard MG, McEniery J and Lambert SB: Epidemiology of Australian influenza-related paediatric intensive care unit admissions, 1997-2013. PLoS One 11: e0152305, 2016.

61. Hardelid P, Kapetanstrataki M, Norman L, Fleming SJ, Lister P, Gilbert R and Parslow RC: Characteristics and mortality risk of children with life-threatening influenza infection admitted to paediatric intensive care in England 2003-2015. Respir Med 137: 23-29, 2018

62. Shang M, Blanton L, Brammer L, Olsen SJ and Fry AM: Influenza-associated pediatric deaths in the United States, 2010-2016. Pediatrics 141: e20172918, 2018.

63. Centers for Disease Control and Prevention: Flu activity and surveillance during the season 2017-2018, 2018. Available at: www.cdc.gov.

64. Hellenic Center for Disease Control and Prevention: Surveillance of influenza in Greece during the period 2017-2018, 2018. Available at: www.keelpno.gr.

65. Sellers SA, Hagan RS, Hayden FG and Fischer WA II: The hidden burden of influenza: A review of the extra-pulmonary complications of influenza infection. Influenza Other Respir Viruses 11: 372-393, 2017.

66. Lefeuvre C, Behillil S, Triau S, Monteiro-Rodrigues A, Templier F, Tran CT, Le Guillou-Guillemette H, Lunel-Fabiani F, Enouf V and Ducancelle A: Fatal myopericarditis following an influenza A (H3N2) infection. Am J Case Rep 19: 540-544, 2018.

67. Mastroyianni SD, Gionnis D, Voudris K, Skardoutsou A and Mizuguchi M: Acute necrotizing encephalopathy of childhood in non-Asian patients: Report of three cases and literature review. J Child Neurol 21: 872-879, 2006.

68. Koutsaftiki C and Papatheodoropoulou A: Participation of paediatric health professionals into the vaccination programme against seasonal influenza. Int J Mol Med 42: S18, 2018.

69. Gilardi F, Castelli Gattinara G, Vinci MR, Ciofi Degli Atti M, Santilli V, Brugaletta R, Santoro A, Montanaro R, Lavorato L, Raponi M, et al: Seasonal influenza vaccination in health care workers. A pre-post intervention study in an italian paediatric hospital. Int J Environ Res Public Health 15: 841, 2018.

70. Levy DJ, Ambrose CS, Oleka N and Lewin EB: A survey of pediatricians' attitudes regarding influenza immunization in children. BMC Pediatr 9: 8, 2009.

71. Jorgensen P, Mereckiene J, Cotter S, Johansen K, Tsolova S and Brown C: How close are countries of the WHO European Region to achieving the goal of vaccinating $75 \%$ of key risk groups against influenza? Results from national surveys on seasonal influenza vaccination programmes, 2008/2009 to 2014/2015. Vaccine 36: 442-452, 2018 
72. Fiore AE, Shay DK, Broder K, Iskander JK, Uyeki TM, Mootrey G, Bresee JS and Cox NS; Centers for Disease Control and Prevention (CDC); Advisory Committee on Immunization Practices (ACIP): Prevention and control of influenza: Recommendations of the Advisory Committee on Immunization Practices (ACIP), 2008. MMWR Recomm Rep 57: 1-60, 2008.

73. Luthy KE, Peterson TB, Macintosh JL, Eden LM, Beckstrand RL and Wiley NH: Evaluation of vaccination policies among Utah pediatric clinic employees. J Pediatr Health Care 30: 190-196, 2016.

74. Tuckerman JL, Collins JE and Marshall HS: Factors affecting uptake of recommended immunizations among health care workers in South Australia. Hum Vaccin Immunother 11: 704-712, 2015.

75. Kuster SP, Shah PS, Coleman BL, Lam PP, Tong A, Wormsbecker A and McGeer A: Incidence of influenza in healthy adults and healthcare workers: A systematic review and meta-analysis. PLoS One 6: e26239, 2011.

76. Mammas IN, Koutsaftiki C, Theodoridou $M$ and Myriokefalitakis N: Vaccination coverage of Greek paediatric healthcare workers against seasonal and A/H1N1 influenza. Acta Paediatr 99: 1114-1115, 2010.

77. Douville LE, Myers A, Jackson MA and Lantos JD: Health care worker knowledge, attitudes, and beliefs regarding mandatory influenza vaccination. Arch Pediatr Adolesc Med 164: 33-37, 2010.

78. Korovessi P: Prevention and management of influenza in childhood: The effect of probiotics. Int J Mol Med 42: S37, 2018.

79. Hasegawa K and Camargo CA Jr: Airway microbiota and acute respiratory infection in children. Expert Rev Clin Immunol 11: 789-792, 2015

80. Homayouni Rad A, Torab R, Mortazavian AM, Mehrabany EV and Mehrabany LV: Can probiotics prevent or improve common cold and influenza? Nutrition 29: 805-806, 2013.

81. Lenoir-Wijnkoop I, Gerlier L, Roy D and Reid G: The clinical and economic impact of probiotics consumption on respiratory tract infections: Projections for Canada. PLoS One 11: e0166232, 2016.

82. Waki N, Matsumoto M, Fukui Y and Suganuma H: Effects of probiotic Lactobacillus brevis KB290 on incidence of influenza infection among schoolchildren: An open-label pilot study. Lett Appl Microbiol 59: 565-571, 2014.
83. Hao Q, Dong BR and Wu T: Probiotics for preventing acute upper respiratory tract infections. Cochrane Database Syst Rev 2: CD006895, 2015

84. Wang Y, Li X, Ge T, Xiao Y, Liao Y, Cui Y, Zhang Y, Ho W, Yu G and Zhang T: Probiotics for prevention and treatment of respiratory tract infections in children: A systematic review and meta-analysis of randomized controlled trials. Medicine (Baltimore) 95: e4509, 2016.

85. Esposito S, Rigante D and Principi N: Do children's upper respiratory tract infections benefit from probiotics? BMC Infect Dis 14: 194, 2014.

86. Amaral MA, Guedes GHBF, Epifanio M, Wagner MB, Jones MH and Mattiello R: Network meta-analysis of probiotics to prevent respiratory infections in children and adolescents. Pediatr Pulmonol 52: 833-843, 2017.

87. Caffarelli C, Cardinale F, Povesi-Dascola C, Dodi I, Mastrorilli V and Ricci G: Use of probiotics in pediatric infectious diseases. Expert Rev Anti Infect Ther 13: 1517-1535, 2015.

88. Yeh TL, Shih PC, Liu SJ, Lin CH, Liu JM, Lei WT and Lin CY: The influence of prebiotic or probiotic supplementation on antibody titers after influenza vaccination: A systematic review and meta-analysis of randomized controlled trials. Drug Des Devel Ther 12: 217-230, 2018

89. Lei WT, Shih PC, Liu SJ, Lin CY and Yeh TL: Effect of probiotics and prebiotics on immune response to influenza vaccination in adults: A systematic review and meta-analysis of randomized controlled trials. Nutrients 9: E1175, 2017.

90. Kwak JY and Lamousé-Smith ESN: Can probiotics enhance vaccine-specific immunity in children and adults? Benef Microbes 8: 657-670, 2017.

91. Zimmermann $\mathrm{P}$ and Curtis $\mathrm{N}$ : The influence of probiotics on vaccine responses - A systematic review. Vaccine 36: 207-213, 2018.

This work is licensed under a Creative Commons Attribution-NonCommercial-NoDerivatives 4.0 International (CC BY-NC-ND 4.0) License. 